\title{
ANTIOXIDANT AND ANTIBACTERIAL ACTIVITY OF ALKALOID EXTRACT OF CUCUMIS TRIGONUS ROXB
}

\author{
PRATIMA H. \\ Department of Post-Graduate Studies and Research in Botany, Akkamahadevi Women's University, Vijayapur, Karnataka, India \\ Email: pratimakalsanki@gmail.com
}

Received: 02 May 2018 Revised and Accepted: 15 Feb 2019

\begin{abstract}
Objective: To evaluate the antioxidant and antibacterial efficiency of alkaloids of root, leaf, and fruit of Cucumis trigonus.

Methods: The antioxidant and antibacterial properties of alkaloid extracts were assessed by ferric thiocynate (FTC), 1, 1-diphenyl-2-picrylhydrazyl (DPPH) radical scavenging assay, hydrogen peroxide radical scavenging assay, superoxide radical scavenging activity and ferric reducing power were analyzed separately for its inhibition percentage at different concentration $(20 \mu \mathrm{g}, 30 \mu \mathrm{g}, 40 \mu \mathrm{g}$ and $50 \mu \mathrm{g} / \mathrm{ml})$ and antibacterial activity by agar disc diffusion and minimum inhibitory concentration (MIC) against Staphylococcus aureus (MTCC Code-9886), Pseudomonas aeruginosa (MTCC Code-6458).

Results: The highest percentage of extraction yield was observed in fruit followed by leaf and root. The maximum content of alkaloid was found in fruit and root compared to leaf. The scavenging efficiencies of the extracts increased with the increasing concentrations. Appreciable levels of total antioxidant activity by FTC $(2.112 \pm 0.011 \%)$, DPPH radical scavenging activity $(1.912 \pm 0.001 \%)$, superoxide radical scavenging activity $(0.955 \pm 0.021 \%)$ and hydrogen peroxide radical scavenging activity $(0.914 \pm 0.087 \%)$ were observed at $50 \mu \mathrm{g} / \mathrm{ml}$ of fruit extract. However, ferric reducing power was more in the root $(0.893 \pm 0.0870 \%)$ compared to fruit $(0.791 \pm 0.023 \%)$ and leaf $(0.520 \pm 0.00 \%)$ at $50 \mu \mathrm{g} / \mathrm{ml}$. The alkaloid extracts of root and fruit exhibited more antibacterial activity against Staphylococcus aureus $(16.51 \pm 0.05$ and $19.68 \pm 0.03 \mathrm{~mm})$ and Pseudomonas aeruginosa $(12.2 \pm 0.03$ and $14.2 \pm 0.06)$ at $100 \mu \mathrm{g} / \mathrm{ml}$ than leaf. The minimum inhibitory concentration (MIC) of the root, leaf, and fruit was in the range of $3.125 \mu \mathrm{g} / \mathrm{ml}$ to $35 \mu \mathrm{g} / \mathrm{ml}$ for the pathogenic bacteria.
\end{abstract}

Conclusion: Data from the present results revealed that the alkaloid extracts of fruit and root of $C$. trigonus show good antioxidant and antibacterial potential than leaf. Hence, may be explored for the formation of new antibacterial with antioxidant drugs.

Keyword: Antioxidant, Antibacterial, Alkaloid, DPPH, Disc diffusion assay

(c) 2019 The Authors. Published by Innovare Academic Sciences Pvt Ltd. This is an open-access article under the CC BY license (http://creativecommons.org/licenses/by/4.0/) DOI: http://dx.doi.org/10.22159/ijpps.2019v11i4.27071

\section{INTRODUCTION}

Natural antioxidants are known to exhibit a wide range of biological effects including antimicrobial, hepatoprotective, anti-inflammatory, anti-allergic, anti-thrombic, anti-carcinogenicity, anti-immunogenicity, and anti-aging activity. The benefit of using natural drugs is their easy availability, economic and no side effects [1]. So, the compounds from natural sources such as phenol, flavonoids, alkaloids etc are capable of protecting against ROS mediated damage may help for the prevention and treatment for various complex diseases. Therefore traditional medicine is an important source of potentially useful new compounds for the development of chemotherapeutic agents.

Cucumis trigonus Roxb. a perennial tendrillar herb of the family Cucurbitaceae commonly called as bitter guard in english, jangal indrayan in hindi, mekke kai in kannad, indravaruni vishala in sanskrit and kattummatti in tamil. It is native to India and is distributed throughout India and also found in Ceylon, Afghanistan, Persia and Northern Australia [2]. In the traditional system of medicine $C$. trigonus root, fruit and seeds have great medicinal values [3]. The roots of the plant are used as purgative and liver tonic. The fruits are used in the treatment of leprosy, fever, jaundice, diabetes, cough, bronchitis, anaemia, constipation, other abdominal disorders and amentia [4]. Further, fruit pulp is bitter, acrid, thermogenic, anthelmintic, liver tonic, cardiotonic, appetizer, expectorant and intellect promoting [2]. Unsaturated lipids are the major constituents of seeds and acts as a coolant and astringent. The Plant is reported to possess proteolytic and serine protease activity [5]. The aqueous fruits extract of $C$. trigonus had beneficial effects in reducing the elevated blood glucose level and lipid profile of STZinduced diabetic rats [6] and also therapeutic and prophylactic value in the treatment of myocardial infarction [7]. The alcoholic fruit extract of $C$. trigonus could afford highly significant protection against $\mathrm{CCl}_{4}$ induced hepatocellular injury [8]. It is a wild vegetable plant with nutritional value is similar to that of cucumber [9]. Due to its wide application in traditional medicine evident from the available literature that the search for natural drugs of plant origin with antibacterial and antioxidant studies has become a central focus of research. Thus, the present study was carried out to provide the scientific evidence by examining the antibacterial and antioxidant activity of alkaloid extract from root, leaf and fruit of $C$. trigonus plant using in vitro assays.

\section{MATERIALS AND METHODS}

\section{Collection of plant materials}

Cucumis trigonus ROXB (Cucurbitaceae) root, leaf, and fruit were collected in the month of November and December form field of Vijayapur district, Karnataka, India. The plant was identified with the help of 'The Flora of the Presidency of Bombay' [10]. The voucher specimen No. 504 has been deposited in the department of Botany, Government college Kalburgi district, Karnataka, India. The plant parts such as root, leaf and fruit were dried in the shade at room temperature between $25-30^{\circ} \mathrm{C}$ for $15-30 \mathrm{~d}$, after drying the plant were chopped and grinded made into fine powder.

\section{Alkaloid extraction}

Alkaloids were extracted from different parts of the selected plant by the well-established method of Ramawat et al., [11]. Finely $100 \mathrm{~g}$ powered sample of plant parts were extracted in $20 \mathrm{ml}$ methanol after shaking of 15 min. After filtration, filtrates kept for drying then residual mass were treated with $1 \% \mathrm{H}_{2} \mathrm{SO}_{4}(5 \mathrm{ml} .2$ times) Extraction was then done in $10 \mathrm{ml}$ of chloroform $\left(\mathrm{CHCl}_{3}\right)$ by using separating funnel. Organic layer of chloroform was rejected and aqueous layer was basified with $30 \% \mathrm{NH}_{4} \mathrm{OH}(\mathrm{pH} 9-10)$. Now again, extraction was done in $10 \mathrm{ml}$ of chloroform and organic layer of chloroform (lower layer) was collected in a flask and repetition of 
step was done with fresh chloroform. The extracts obtained were dried at $40^{\circ} \mathrm{C}$ for further use.

\section{Yields of extracts}

The yields of the extracts were calculated using the following formula $[12,13]$.

$$
\text { Percentage of extractive value }=\frac{\text { Weight of the residue obtained }}{\text { Weight of the plant material taken }} \times 100
$$

\section{Estimation of total alkaloid}

The alkaloid was estimated by the method of Harborne [14]. The acetic acid (5\%) extract of the plant material was warmed up to 70 ${ }^{\circ} \mathrm{C}$ and the $\mathrm{pH}-10$ was made by $\mathrm{NH}_{4} \mathrm{OH}$ and centrifuged at $5000 \mathrm{rpm}$. The precipitate was dissolved in ethanol (95\%) and $\mathrm{H}_{2} \mathrm{SO}_{4}$. The alkaloid solution was mixed with $5 \mathrm{ml}$ of $60 \% \mathrm{H}_{2} \mathrm{SO}_{4}$ after $5 \mathrm{~min}, 5 \mathrm{ml}$ of the solution of formaldehyde in $\mathrm{H}_{2} \mathrm{SO}_{4}$ was added. The solution was read at $565 \mathrm{~nm}$ absorbance after $15 \mathrm{~min}$ the amount of alkaloids was calculated using the standard curve of brucine.

\section{Analysis of in vitro antioxidant activity}

The different concentration of alkaloid extract $(20 \mu \mathrm{g}, 30 \mu \mathrm{g}, 40 \mu \mathrm{g}$, $50 \mu \mathrm{g}$ ) of root, leaves and fruit samples of $C$. trigonus were tested for their in vitro antioxidant activity as follows.

\section{Evaluation of antioxidant activity by ferric thiocynate (FTC) method}

FTC method used to determine the amount of peroxide formed and that react with ferrous chloride $\left(\mathrm{FeCl}_{2}\right)$ pigment, the concentration of peroxide decreases the same as the antioxidant activity increases. The antioxidant activities of extracts were determined by ferric thiocynate method [15]. The sample mixture contains $0.5 \mathrm{ml}$ of extract, $2.5 \mathrm{ml}$ of linoleic acid emulsion in potassium phosphate buffer $(0.05 \mathrm{M} \mathrm{pH} 7.0)$ and $2 \mathrm{ml}$ phosphate buffer $(0.05 \mathrm{M} \mathrm{pH} 7.0)$ in a test tube and incubated in darkness at $37^{\circ} \mathrm{C}$. The peroxide level was measured at $500 \mathrm{~nm}$ in a spectrophotometer. Ascorbic acid was used as positive control.

\section{Evaluation of free radical scavenging activity by DPPH method}

The DPPH (1, 1-diphenyl-2-picrylhydrazyl) method allows a direct investigation of the ability for the extractor antioxidant to donate hydrogen and/or electrons to quench the DPPH radical. The potential antioxidant activity of extract was determined on the basis of scavenging activity of the stable DPPH free radicals by the method of Blois [16]. $0.1 \mathrm{ml}$ of sample at various concentrations was mixed with $2.9 \mathrm{ml}$ of methanolic DPPH $(60 \mu \mathrm{M})$ solution. The mixture was left in the dark for $30 \mathrm{~min}$ and absorbance was measured at $517 \mathrm{~nm}$.

\section{Assay of superoxide radical scavenging activity}

The method by Martinez et al., [17] for determination of the superoxide dismutase was followed with modification in the riboflavin-lightonitroblueretrazolium (NBT) system. Each $3 \mathrm{ml}$ reaction mixture contained $50 \mathrm{mmol}$ sodium phosphate buffer $\mathrm{pH}$ 8.8), $13 \mathrm{mmol}$ methionine, $2 \mu \mathrm{M}$ riboflavin, $100 \mu \mathrm{M}$ EDTA, $75 \mu \mathrm{M}$ NBT and $500 \mu \mathrm{l}$ sample solution of various concentrations alkaloid extracts was measured at $560 \mathrm{~nm}$ and compared with ascorbic acid as a standard compound. The percentage of inhibition was calculated according to the following equation

$$
\text { Percentage of inhibition }=[(\mathrm{A} 0-\mathrm{At}) / \mathrm{A} 0] \times 100 \text {, }
$$

Where $\mathrm{A} 0$ was the absorbance of the control (blank) and at was the absorbance in the presence of each extract.

\section{Hydrogen peroxide radical scavenging activity}

Hydrogen peroxide radical scavenging ability of alkaloid extracts were assessed by adopting the method given by Ruch et al. [18]. A solution of hydrogen peroxide $(2 \mathrm{mmol})$ was prepared in phosphate buffer $(0.2 \mathrm{M}, \mathrm{pH}$ 7.4). Extracts in different concentrations were added to a hydrogen peroxide solution $(0.6 \mathrm{ml}, 2 \mathrm{mmol})$. The absorbance of hydrogen peroxide at $230 \mathrm{~nm}$ was determined 10 min later against a blank solution containing the phosphate buffer without hydrogen peroxide. The percentage of hydrogen peroxide scavenging of both extracts and standard compounds were calculated using formula.

$$
\text { Percentage of inhibition }=\frac{\text { Abs (control })- \text { Abs (test })}{\text { Abs (control) }} \times 100
$$

Where Abs (control): Absorbance of the control and

Abs (test): Absorbance of the extract/standard

\section{Determination of ferric reducing power}

The reducing power of the prepared extracts was determined using ferricyanide trichloroacetic acid method according to Oyaizu [19]. Each sample extract was mixed with $200 \mathrm{mmol}$ phosphate buffer $(\mathrm{pH}$ 6.6) and with $1 \%$ potassium ferricyanide in the ratio of $1: 1(\mathrm{v} / \mathrm{v})$ and the mixture was incubated at $50{ }^{\circ} \mathrm{C}$ for $20 \mathrm{~min}$. After $2.5 \mathrm{ml}$ of $10 \%$ trichloroacetic acid $(\mathrm{w} / \mathrm{v})$ was added, the mixture was centrifuged at $659 \mathrm{rpm}$ for $10 \mathrm{~min}$. The upper layer was mixed equally with deionized water and $1 \mathrm{ml}$ of $0.1 \%$ ferric chloride and the absorbance was measured at $700 \mathrm{~nm}$. A higher absorbance indicates a higher reducing power.

\section{Antimicrobial activity}

Pathogens used

The pure axenice culture of bacteria Staphylococcus aureus (MTCC Code-9886), Pseudomonas aeruginosa (MTCC Code-6458) (microbial type culture collection) were obtained from institute of microbial technology, Chandigarh. All the cultures were maintained at $4{ }^{\circ} \mathrm{C}$ on the slants of nutrient agar medium for further use.

\section{Reconstitution of the extracts}

The alkaloid extracts were dissolved in dimethyl sulfoxide (DMSO) and the final concentrations of the crude extract solution were obtained as $50 \mu \mathrm{g} / \mathrm{ml}$ and $100 \mu \mathrm{g} / \mathrm{ml}$ respectively

\section{Antibacterial activity}

The extracts were screened for their antibacterial activity in comparison with standard Streptomycin $(10 \mathrm{mg} / \mathrm{ml})$ in vitro by agar well diffusion method [20]. The petri plates containing $15-20 \mathrm{ml}$ of Muller Hinton Agar (MHA) medium was inoculated with $200 \mu \mathrm{l}$ of $18 \mathrm{~h}$ old bacterial culture was evenly spread with a sterile bent glass rod. The inoculated plates are kept aside for few minutes. A sterile cork borer was then used to make four wells ( $8 \mathrm{~mm}$ diameter) for different concentrations of the extract, on each of the plates containing cultures of the different test organisms. The four peripheral wells were filled with $100 \mu \mathrm{l}$ of each crude extracts of the concentration 50 and $100 \mu \mathrm{g} / \mathrm{ml}$ respectively. In the similar way, one agar plates for each microorganism were prepared for studying the antibacterial activity of reference compound Streptomycin $(100 \mu \mathrm{g} / \mathrm{ml})$. For assaying antibacterial activity, plates were incubated at $37{ }^{\circ} \mathrm{C}$ for $24 \mathrm{~h}$. The diameter of the zone of inhibition (in $\mathrm{mm}$ ) was recorded.

\section{Minimum inhibitory concentration (MIC)}

The MIC of the extracts was determined according to the macro broth dilution technique [21]. Standardized suspensions of the test organisms were inoculated into a series of sterile tubes of nutrient broth containing two-fold dilution of leaf extracts and incubated at $37{ }^{\circ} \mathrm{C}$ for $24 \mathrm{~h}$. MICs were read as the least concentration that inhibited the growth of the test organisms.

\section{Statistical analysis}

The data of all measurements are means from three replications. Data and statistical significance of difference were evaluated with analysis of variance (ANOVA) using SPSS 10.0 package.

\section{RESULTS}

\section{Extractive values and total alkaloid contents}

The percentage of the extractive value of root, leaf and fruit of $C$. trigonus were recorded in the table 1 . The yield of alkaloid extracts were $5.14 \%$ to $11.36 \%$ and could be ranked from high to low i.e., fruit $>$ root $>$ leaf respectively. Further, the results shows that the fruit contain higher amount of total alkaloid $(193.22 \pm 0.82 \mathrm{mg} / \mathrm{g})$ compared to root $(162.02 \pm 0.23 \mathrm{mg} / \mathrm{g})$ and leaf $(76.34 \pm 0.03 \mathrm{mg} / \mathrm{g})$ (table 1). 
Table 1: Extractive value and total alkaloids of $C$. trigonus

\begin{tabular}{lll}
\hline Plant part & \% yield of extract & Total alkaloid mg/g brucin equivalent \\
\hline Root & $9.34 \pm 0.12$ & $162.02 \pm 0.23$ \\
Leaf & $5.14 \pm 0.10$ & $76.34 \pm 0.03$ \\
Fruit & $11.36 \pm 0.05$ & $193.22 \pm 0.82$ \\
\hline
\end{tabular}

Each value is expressed as mean \pm SD $(n=3)$ and means are different from each other by ANOVA $(P<0.05)$.

\section{Total antioxidant activity by FTC method}

Total antioxidant activity by FTC method of root, leaf, and fruit of alkaloid extracts increased readily along the increased concentration (table 2). At higher concentration of $50 \mu \mathrm{g} / \mathrm{ml}$ antioxidant activity was in the order; fruit extract $(2.019 \pm 0.022 \%)>$ root extract $(1.08 \pm 0.023 \%)>$ leaf extract $(0.724 \pm 0.034 \%)$. The maximum antioxidant activity was observed in fruit extract $(2.019 \pm 0.022 \%)$ and most nearer to the standard ascorbic acid $(2.112 \pm 0.011 \%)$ at 50 $\mu \mathrm{g} / \mathrm{ml}$ concentration.

\section{DPPH radical scavenging activity}

Results show that the free radical scavenging activity of root, leaf and fruit of alkaloid extracts of $C$. trigonus increased with the increasing concentration were presented in table 3 . Radical scavenging activity at higher concentration $50 \mu \mathrm{g} / \mathrm{ml}$ of root, leaf and fruit extracts were found to be $0.830 \pm 0.005 \%, 0.634 \pm 0.003 \%$ and $1.598 \pm 0.002 \%$ respectively. Root and leaf extract shows much lower radical scavenging activity. The significant free radical scavenging activity was observed in fruit extract $(1.912 \pm 0.001 \%)$ and it was higher than the standard ascorbic acid (1.598 $\pm 0.002 \%)$ at $50 \mu \mathrm{g} / \mathrm{ml}$ concentration.

\section{Assay of superoxide radical scavenging activity}

Superoxide radical scavenging activity of root, stem and leaf of $C$. trigonus increases with increasing concentration (table 4). The maximum superoxide radical scavenging activity was observed in fruit $(0.955 \pm 0.021 \%)$ compared to root $(0.734 \pm 0.007 \%)$ and leaf $(0.571 \pm 0.002 \%)$ at $50 \mu \mathrm{g} / \mathrm{ml}$ similarly, the scavenging activity of ascorbic acid at the same concentration was $1.451 \pm 0.012 \%$.

Table 2: Total antioxidant activity by FTC method of alkaloid extract of $C$. trigonus

\begin{tabular}{llll}
\hline Plant parts & \% of inhibition & \\
\cline { 2 - 4 } & $\mathbf{2 0 \mu g}$ & $\mathbf{3 0 \mu}$ & $\mathbf{4 0 \mu g}$ \\
\hline Root & $0.453 \pm 0.023$ & $0.725 \pm 0.018$ & $0.798 \pm 0.009$ \\
Leaf & $0.298 \pm 0.012$ & $0.392 \pm 0.015$ & $0.478 \pm 0.022$ \\
Fruit & $0.632 \pm 0.015$ & $0.895 \pm 0.032$ & $1.378 \pm 0.018$ \\
Standard ascorbic acid & $0.814 \pm 0.022$ & $0.923 \pm 0.045$ & $1.08 \pm 0.023$ \\
\hline
\end{tabular}

Each value is expressed as mean $\pm \mathrm{SD}(\mathrm{n}=3)$ and means are different from each other by ANOVA $(P<0.05)$.

Table 3: DPPH radical scavenging activity of alkaloid extract of $C$. trigonus

\begin{tabular}{llll}
\hline Plant parts & \% of inhibition & \\
\cline { 2 - 4 } & $\mathbf{2 0 \mu g}$ & $\mathbf{3 0 \mu g}$ & $\mathbf{4 0 \mu g}$ \\
\hline Root & $0.289 \pm 0.005$ & $0.602 \pm 0.003$ & $0.710 \pm 0.001$ \\
Leaf & $0.193 \pm 0.005$ & $0.361 \pm 0.008$ & $0.423 \pm 0.004$ \\
Fruit & $0.398 \pm 0.004$ & $0.821 \pm 0.003$ & $1.206 \pm 0.008$ \\
Standard ascorbic acid & $0.543 \pm 0.002$ & $0.886 \pm 0.005$ & $1.426 \pm 0.004$ \\
\hline
\end{tabular}

Each value is expressed as mean $\pm \mathrm{SD}(\mathrm{n}=3)$ and means are different from each other by ANOVA $(P<0.05)$.

\section{Hydrogen peroxide radical scavenging activity}

Results show that the hydrogen peroxide radical scavenging activity of root, leaf and fruit of $C$. trigonus alkaloid extracts increased with the increasing concentration and were high for fruit ant root, the leaf extract shows much lower radical scavenging activity (Table-5). Radical scavenging activity at a concentration of $50 \mu \mathrm{g} / \mathrm{ml}$ of root, leaf and fruit extracts were found to be $0.751 \pm 0.023 \%, 0.318 \pm 0.010 \%$ and $0.984 \pm 0.087 \%$ respectively however, the scavenging activity of ascorbic acid at the same concentration was $2.05 \pm 0.028 \%$.

Table 4: Superoxide radical scavenging activity of alkaloid extract of $C$. trigonus

\begin{tabular}{|c|c|c|c|c|}
\hline \multirow[t]{2}{*}{ Plant parts } & \multicolumn{4}{|c|}{$\%$ of inhibition } \\
\hline & $20 \mu \mathrm{g}$ & $30 \mu \mathrm{g}$ & $40 \mu \mathrm{g}$ & $50 \mu \mathrm{g}$ \\
\hline Root & $0.131 \pm 0.002$ & $0.446 \pm 0.004$ & $0.602 \pm 0.002$ & $0.734 \pm 0.007$ \\
\hline Leaf & $0.114 \pm 0.003$ & $0.297 \pm 0.006$ & $0.410 \pm 0.007$ & $0.571 \pm 0.002$ \\
\hline Fruit & $0.422 \pm 0.006$ & $0.780 \pm 0.002$ & $0.984 \pm 0.005$ & $0.955 \pm 0.021$ \\
\hline Standard ascorbic acid & $0.650 \pm 0.001$ & $0.723 \pm 0.012$ & $0.989 \pm 0.023$ & $1.451 \pm 0.012$ \\
\hline
\end{tabular}

Each value is expressed as mean $\pm \mathrm{SD}(\mathrm{n}=3)$ and means are different from each other by ANOVA $(P<0.05)$.

Table 5: Hydrogen peroxide scavenging activity of alkaloid extracts of $C$. trigonus

\begin{tabular}{llll}
\hline Plant parts & \% of inhibition & \\
\cline { 2 - 4 } & $\mathbf{2 0 \mu g}$ & $\mathbf{3 0 \mu g}$ & $\mathbf{4 0 \mu g}$ \\
\hline Root & $0.426 \pm 0.005$ & $0.631 \pm 0.011$ & $0.730 \pm 0.003$ \\
Leaf & $0.145 \pm 0.012$ & $0.234 \pm 0.021$ & $0.285 \pm 0.008$ \\
Fruit & $0.508 \pm 0.005$ & $0.669 \pm 0.005$ & $0.848 \pm 0.034$ \\
Standard ascorbic acid & $0.780 \pm 0.021$ & $0.812 \pm 0.009$ & $0.751 \pm 0.023$ \\
\hline
\end{tabular}

Each value is expressed as mean $\pm \mathrm{SD}(\mathrm{n}=3)$ and means are different from each other by ANOVA $(P<0.05)$. 


\section{Determination of ferric reducing power}

Reducing the power of root, leaf and fruit extracts from C. trigonus increased readily along the increased concentrations (table 6). At concentration of $50 \mu \mathrm{g} / \mathrm{ml}$, reducing power were in the order; root
$(0.893 \pm 0.087 \%)>$ fruit $\quad(0.791 \pm 0.023 \%)>$ leaf $\quad(0.520 \pm 0.005 \%)$. However, reducing the power of ascorbic acid at $50 \mu \mathrm{g} / \mathrm{ml}$ was $1.451 \pm 0.012 \%$. The maximum percentage of reducing power was detected in root compared to fruit and leaf.

Table 6: Ferric reducing power of alkaloid extract of $C$. trigonus

\begin{tabular}{llll}
\hline Plant parts & \% of inhibition & \\
\cline { 2 - 4 } & $\mathbf{2 0 \mu g}$ & $\mathbf{3 0 \mu}$ & $\mathbf{4 0 \mu g}$ \\
\hline Root & $0.526 \pm 0.005$ & $0.631 \pm 0.011$ & $0.830 \pm 0.003$ \\
Leaf & $0.212 \pm 0.007$ & $0.344 \pm 0.015$ & $0.405 \pm 0.001$ \\
Fruit & $0.408 \pm 0.005$ & $0.569 \pm 0.005$ & $0.748 \pm 0.034$ \\
Standard ascorbic acid & $0.650 \pm 0.001$ & $0.723 \pm 0.012$ & $0.989 \pm 0.023$ \\
\hline
\end{tabular}

Each value is expressed as mean $\pm \operatorname{SD}(n=3)$ and means are different from each other by ANOVA $(P<0.05)$.

\section{Antibacterial activity}

The antibacterial efficacy of alkaloid extracts from root, leaf and fruit of $C$. trigonus was determined by screening extracts against Grampositive bacteria of Staphylococcus aureus and Gram-negative bacteria of Pseudomonas aeruginosa. All the extracts were found active against all the test bacterial strains (table 7). In this assay, the leaf extract shows less inhibition zone against Staphylococcus aureus $(1.36 \pm 0.04 \mathrm{~mm})$ and Pseudomonas aeruginosa $(1.2 \pm 0.03 \mathrm{~mm})$ at $50 \mu \mathrm{g} / \mathrm{ml}$. The root extract shows moderate inhibition zone against Staphylococcus aureus $(10.51 \pm 0.05 \mathrm{~mm})$ and Pseudomonas aeruginosa $(12.2 \pm 0.03 \mathrm{~mm})$. However the fruit extracts exhibited higher antibacterial activity against Staphylococcus aureus $(19.68 \pm 0.03 \mathrm{~mm})$ then Pseudomonas aeruginosa $(14.2 \pm 0.06 \mathrm{~mm})$ at $50 \mu \mathrm{g} / \mathrm{ml}$ this is a significant activity compared with the activity of the standard streptomycin which show zone of inhibition of $22.0 \pm 0.05 \mathrm{~mm}$ (against Staphylococcus aureus) and $20.0 \pm 0.07 \mathrm{~mm}$ (against Pseudomonas aeruginosa) at $50 \mu \mathrm{g} / \mathrm{ml}$.

\section{Minimum inhibitory concentration}

The MIC method was applied on extracts has proved their high efficacy against microorganisms by the disc diffusion method. The MIC of root, leaf and fruit extract as shown in table 8. The extract had MIC values of 3.125 to $35 \mu \mathrm{g} / \mathrm{ml}$ against both strains. The fruit and root extracts of $C$. trigonus showed highest sensitivity at $3.125 \mu \mathrm{g} / \mathrm{ml}$ and $5.125 \pm 0.5 \mu \mathrm{g} / \mathrm{ml}$ against Staphylococcus aureus and at $4.5 \mu \mathrm{g} / \mathrm{ml}$ and $7.35 \mu \mathrm{g} / \mathrm{ml}$ against Pseudomonas aeruginosa. The leaf extract had weak activity with MIC values of $35 \mu \mathrm{g} / \mathrm{ml}$ against Staphylococcus aureus and $32 \mu \mathrm{g} / \mathrm{ml}$ against Pseudomonas aeruginosa.

Table 7: Antibacterial activity of alkaloid extracts of $C$. trigonus

\begin{tabular}{llll}
\hline Plant parts & Conc. $(\boldsymbol{\mu g} / \mathbf{m l})$ & Diameter of the zone of inhibition $(\mathbf{m m})$ & \\
\cline { 3 - 4 } & & Staphylococcus aureus & Pseudomaonas aeruginosa \\
\hline Root & 50 & $10.3 \pm 0.03$ & $12.2 \pm 0.02$ \\
& 100 & $16.51 \pm 0.05$ & $0.48 \pm 0.05$ \\
Leaf & 50 & $0.87 \pm 0.02$ & $1.2 \pm 0.03$ \\
& 100 & $1.36 \pm 0.04$ & $11.5 \pm 0.08$ \\
Fruit & 50 & $15.3 \pm 0.05$ & $14.2 \pm 0.06$ \\
& 100 & $19.68 \pm 0.03$ & $20.0 \pm 0.07$ \\
Streptomycin & 100 & $22.0 \pm 0.05$ & \\
\hline
\end{tabular}

Each value is expressed as mean $\pm \mathrm{SD}(\mathrm{n}=3)$ and means are different from each other by ANOVA $(P<0.05)$.

Table 8: Minimum inhibitory concentration of alkaloid extracts of $C$. trigonus

\begin{tabular}{llll}
\hline Microorganism & \multicolumn{4}{l}{ Gradient of extract $\boldsymbol{\mu g} / \mathbf{m l}$} & Fruit \\
\cline { 2 - 4 } & Root & Leaf & $3.125 \pm 0.15$ \\
\hline Staphylococcus aureus & $5.125 \pm 0.5$ & $35 \pm 0.12$ & $4.5 \pm 0.6$ \\
Pseudomaonas aeruginosa & $7.35 \pm 0.8$ & $32 \pm 0.15$ & \\
\hline
\end{tabular}

Each value is expressed as mean $\pm \mathrm{SD}(\mathrm{n}=3)$ and means are different from each other by ANOVA $(P<0.05)$.

\section{DISCUSSION}

The result of our study showed that the alkaloid extract of fruit gives the highest yield and total alkaloid content than root and leaf extract. This can be explained by the distribution of compounds in the plant part. Bousselessela et al., [22] have reported yield of neutral alkaloid extract $12.07 \%$ and basic alkaloid extract $(3.07 \%)$ in leaf of Euphorbia granulate. The researchers have recorded total alkaloid contents of $0.87 \mathrm{mg} / \mathrm{kg}$ of fruit of $C$. trigonus [23]. Alkaloids have a wide range of pharmacological activities including anticancer and antibacterial activities and hence responsible for many healing properties in natural medicine.

Total antioxidant assay using FTC, which indicates the ability of the phytomedicines to minimize oxidative damage to vital organs and tissues in vivo. The results of total antioxidant activity by FTC method revealed that alkaloid extract of fruit had maximum antioxidant activity than the other extract. There are reports on the alkaloid extracts of two Algerian species of Fumaria capreolata and Fumaria bastardii had more antioxidant activity by FTC method [24]. Results of the investigation revealed that alkaloid fruit and root extract showed a relatively high DPPH radical scavenging activity than leaf at $50 \mu \mathrm{g} / \mathrm{ml}$. Similarly Gill et al., [25] have reported the highest free radical scavenging activity of methanolic extract of seeds of $C$. trigonus. The reports has shown that alkaloids extracts of Euphorbia granulate leaf was shown a great antiradical activity by the characterization of several substances which inhibit free radical DPPH [22]. Further, Rosidah et al., [26] have reported that alkaloid fractions of $Z$. acanthopodium DC. fruit have very strong antioxidant potential by DPPH method. Superoxide radical is known to be very harmful to cellular components as a precursor of more reactive 
species. One risk of the superoxide generation is related to its interaction with nitric oxide to form peroxinitrite [27] which is a potent oxidant that causes nitrosative stress in the organ systems. Scavenging of $\mathrm{H}_{2} \mathrm{O}_{2}$ by the extract may be attributed to the compounds, which can donate electrons to $\mathrm{H}_{2} \mathrm{O}_{2}$, thus neutralizing it to water [28]. Gill et al., [25] have reported the maximum $\mathrm{H}_{2} \mathrm{O}_{2}$ scavenging effect of methanolic extract of seeds of $C$. trigonus. The reducing power increased with increasing the concentration of the extract. The reducing ability of the compound may provide a significant indicator of its effective antioxidant activity [29]. The absorbance values of the extract at different concentrations was found to be less than that of the reference compound and this is in accordance with the report of Gulcin et al., [30].

From the results of our study, the maximum inhibition zone was shown by the alkaloid extract of fruit against $S$. aureus and $P$. aeruginosa at a concentration of $100 \mu \mathrm{g} / \mathrm{ml}$ than root and leaf extract. Bousselessela et al., [22] have reported the largest zone of growth inhibition was shown by the neutral alkaloids extract Euphorbia granulate against $S$. aureus at a concentration of 10 $\mathrm{mg} / \mathrm{ml}$. The Gram-positive bacteria are much more sensitive than Gram-negative bacteria this sensibility can be attributed to the structure of bacteria [31].

\section{CONCLUSION}

The alkaloid extract of root, leaf and fruit of $C$. trigoonus exhibited moderate to high antioxidant and antibacterial activity against Staphylococcus aureus and Pseudomonas aeruginosa. The alkaloid fruit and root extract of $C$. trigoonus is more active than leaf extract. It further exhibited good electron donating ability, which implies that alkaloids may be inhibiting some redox pathways in the bacterial cell, thereby slow the growth or even cause death of a microbe. This antioxidant property adds value to the potential antibacterial efficacy of the alkaloids from the fruit and roots of $C$. trigonus hence, the need to explore further pharmacological effects and safety

\section{ACKNOWLEDGMENT}

The authors are thankful to the Dr. Babu R. L. Coordinator, Department of Botany, Akkamahadevi Women's University Vijayapura, India for providing the laboratory facilities.

\section{AUTHORS CONTRIBUTIONS}

All the author have contributed equally

\section{CONFLICT OF INTERESTS}

The authors of this article declare that we have no conflict of interest in this study

\section{REFERENCES}

1. Alagar Raja M, Sahithi G, Vasanthi R, David Banji, Rao KNV, Selvakumar D. Study of phytochemical and antioxidant activity of Cucumis fruit. J Pharmacogn Phytochem 2015;4:303-6.

2. Kiritikar KR, Basu BD. Indian medicinal plants. Vol. 1. International Publishers 2Edn. Dehradun; 1999.

3. Naveena BM, Mendiratta SK, Anjaneyulu AS. Tenderization of buffalo meat using plant proteases from Cucumis trigonus Roxb (Kachri) and Zingiber officinale roscoe (Ginger rhizome). Meat Sci 2004;68:363-9.

4. Naik VR, Agshikar NV, Abraham GJ. Diuretic activity of Cucumis trigonus ROXB. J Ethanopharmacol 1981;3:15-9.

5. Naik VR, Agshikar NV, Abraham GJ. Analgesic and antiinflammatory activity in alcoholic extracts of Cucumis trigonus ROXB. A preliminary Communication. Pharmacology 1980;20:52-6.

6. Salahuddin MD, Jalalpure SS. Antidiabetic activity of aqueous fruits extract of Cucumis trigonus Roxb. In streptozotocininduced diabetic rats. J Ethanopharmacol 2010;127:565-7.

7. Thippeswamy BS, Thakker SP, Tubachi S, Kalyani GA, Netra MK, Patil Ulubelen A. Identification of steroidal and triterpenic compounds of Cucumis trigonus. Planta Med 1976;30:144-5.

8. Patil K, Mohammed Imtiaz S, Singh A, Bagewadi V, Gazi S. Hepatoprotective activity of Cucumis trigonus roxb. fruit against $\mathrm{CCl}_{4}$ induced hepatic damage in rats. Iranian J Pharma Res 2011;10:295-9.

9. Mangan F, Moreira M, Barros Z, Fernandes C, Mateus R, Finger $\mathrm{F}$, et al. Research and extension activities implemented by the Umass ethnic crop program in 2009. Veg Note Veg Farmers 2010;21:1-16.

10. Cooke T. Lamiaceae. In: The flora of the presidency of Bombay. Vol. 1. Taylor and Francis, London; 1906.

11. Ramawat KG, Merillon JM. Biotechnology regulator of gene expression in the vasculature. Circ Res 2000;85:753-66.

12. Raghunathan K. Pharmacopoeial standards for ayurvedic formulations. Central council for Research in Indian Medicine and Homeopathy, E-25, Defense colony, New Delhi; 1976.

13. Usha Shome, Joshi P, Sharma HP. Pharmacognostic studies on Atemisia Scoparia Waldst and kit. Proc Indian Acad Sci (Plant Sci) 1984;93:151-64.

14. Harborne JB. The terpenoids. In: Phytochemical methods. Vol. 3. Chapman and Hall, London; 1973.

15. Mistuda H, Yuasumoto K, Iwami. Antioxidation action of Indole compounds during the antioxidation of linoliec acid. Nihon Eiyo Shokuryo Gakkai-Shi 1996;19:210-4.

16. Blois MS. Antioxidant determinations by the use of a stable free radical. Nature 1958;26:1199-200.

17. Matinez AC, Marcelo EL, Marco AO, Moacyr M. Different responses of superoxide dismutase in freezing resistant Solanum curtibolum and freezing sensitive Solanum tuberosum subjected to oxidative and water stress. Plant Sci 2001;160:505.

18. Ruch RJ, Cheng SJ, Klaunig JE. Prevention of cytotoxicity and inhibition of intercellula communication by antioxidant catechins isolated from Chinese green tea. Carcinogenesis 1989;10:1003-8.

19. Oyaizu M. Studies on product of browning reaction prepared from glucose amine. Japan J Nutr 1986;44:307-15.

20. Indian Pharmacopoeia. Government of India, Ministry of Health and Family Welfare, Published by the Controller of Publications, Delhi; 1996.

21. Baron JE, Finegold SM. Methods of testing antimicrobial effectiveness. In: Bailey scotts Diagonostia. Microbiology. Mosby C Missouri; 1990. p. 171-94.

22. Bousselessela H, Yahia M, Mahboubi A, Benbia S, Yahia Massinissa. Antioxydant and antibacterial activity of alkaloids and terpenes extracts from Euphorbia granulate. Int J Bioengineering Life Sci 2013; 7:166-9.

23. Gopalkrishnan S, Kalaiarasi T. Comparative phytochemical screening of the fruits of Cucumis trigonus ROXB and Cucumis sativus Linn. World J Pharm Pharm Sci 2014;3:1455-6.

24. Maiza Benabdesselam F, Khentache S, Bougoffa K, Chibane M, Adach S, Chapeleur Y, et al. Antioxidant activities of alkaloid extracts of two algerian species of Fumaria: Fumaria capreolata and Fumaria bastardii. Rec Nat Prod 2007;1:28-35.

25. Gill NS, Gaurav Sharma, Rashmi Arora. Isolation and characterization of Cucumis trigonus ROXB. seeds for their therapeutic potential. Int J Univers Pharm Bio Sci 2014;3:234-46.

26. Rosidah, Poppy Anjelisa Zaitun Hasibuan, Ginda Haro, Puteri Masri, Denny Satria. Antioxidant activity of alkaloid fractions of Zanthoxylum acanthopodium DC. fruits with 1,1-Diphenyl-2picrylhydrazyl assay. Asian J Pharma Clin Res 2018;11:33-4.

27. Yamagishi SI, Edelstein D, Du XL, Brownlee M. Hyperglycaemic potentials collagen-induced platlet activation through mitochondrial superoxide overproduction. Diabetes 2001;50:1491.

28. Halliwell B, Gutteridge JMC. Free radicals in biology. Vol. 87. University Press; 1985.

29. Meir S, Kanner J, Akiri B, Hadas SP. Determination and involvement of aqueous reducing compound in oxidative defense systems of various senescing leaves. J Agric Food Chem 1995;43:1813-7.

30. Gulcin I, Oktay M, Kufrevioglu OI, Aslan A. Determination of antioxidant activity of lichen Cetraria islandica L. Ach J Ethnopharmacol 2002;79:325-9.

31. Perry JJ, Staley JT. Microbiology. Sounders college publishing, New York: U. S. A; 1997. 